\title{
The rhetoric of Australia's regional policy
}

\author{
James Cotton
}

Discussing the evolution of Australia's regional policy involves making some assessment of conflicting partisan claims as to its invention and promotion. Former Prime Ministers Paul Keating (1991-96) and Gough Whitlam (1972-75) both claim to have invented the idea of pursuing engagement or community in the Asiam Pacific region and both wrote books advancing their respective claims (Whitlam 1981; Keating 2000). On the conservative side of politics, Percy Spender (Foreign Minister 1949-51) and R.G. Casey (Foreign Minister 1951-60, later head of state) paid great attention to diplomacy in the Asian region and also wrote books on this theme (Spender 1969; Casey 1955). Nor is this a matter only of historical interest. In the 1990s one feature of election rhetoric has been the charge that one side of politics or the other cannot be entrusted with government since they did not have regional credibility or, alternatively, could not advance Australia's regional interests without compromising important values.

Setting aside these partisan questions, Australia's regional policy rests on several key geo-political legacies. Australia is a largely European derived society on the fringes of the Asian land mass. It is sparsely inhabited yet its armed forces must defend an entire continent. Australia's security has traditionally been sought through alliances or cooperation with extra-regional powers, first with Great Britain and from 1942 with the United States. This strategy has generally served Australia well, and it is popularly believed that only the US commitment to defend Australia prevented a Japanese invasion during the Second World War. However, there have been important occasions when there were doubts that these partners had Australia's security as their highest priority, a historical record that has also perpetuated a sense of strategic uncertainty. Perhaps the most famous episode was the attempt by British Prime Minister Churchill in February 1942 to divert Australian troops returning from the Middle East for the campaign in Burma when the Australian government was expecting their return for the defence of the homeland (Grey 1999, 168). Similarly, Australian policymmakers were 
disappointed to find, in 1961, that the United States was prepared to support the Indonesian acquisition of West Papua in the interests (as was the perception in Washington) of keeping Jakarta out of the communist bloc even though this was anathema to the Menzies government (Pemberton 1987, 70-106). As a consequence, Australia then came to share an ill-defined border with Indonesia under the unpredictable and increasingly leftist leadership of Sukarno. Australia's commitment of troops to the Vietnam War (despite the domestic turmoil this generated) can be partly understood as an attempt to help secure long-term US involvement in Australia's immediate region (Edwards 1992, 358-62). At that time, of course, it was not imagined that once committed, the US would not prevail.

The other legacy that has had an enduring impact has been the radical reorientation of economic linkages. Even in the 1930s, signs emerged of economic complementarity between Australia and Japan, though at that time Britain accounted for more than half of all Australia's trade and the majority of foreign investment. In the immediate post-war period Britain resumed its role as chief trading partner, but through to the 1970 s this predominance of British linkages progressively declined. By 1970 Japan had become the single largest destination for Australian exports, a trend encouraged further by the loss of major markets when, to the dismay of many in Australia, Britain joined the (then) EEC in 1973. By this time trade with the US was very significant, and investment from the US and (later) from Japan grew to rival levels of British investment, an issue vital in a nation traditionally dependent upon the importation of capital (Meredith and Dyster 1999, 192-221; Tweedie 1994).

These security and economic developments need to be seen in a social context. For almost the first half of its life, the Australian federation was avowedly an Anglo-Celtic country. By degrees this position was abandoned, first regarding immigration from the European area, and then from Asia. By 1966, exclusions on immigration on the grounds of race were abandoned and in 1973, an explicitly nondiscriminatory definition of Australian citizenship was enacted. By the early 1980 s 'Asia' outpaced 'Europe' as the largest source of immigrants, and of the former group those from Hong Kong were the most numerous (Mackie 1997, 18-24). The era of Australian 'multiculturalism' had begun. This trend coalesced with what by now was the dominant cultural view that being 'Australian' entailed a distinctive and unique national consciousness.

If emerging economic complementarities and immigration trends were the most noticeable form of regional engagement, other developments were also important. Through the 1970s the foundations were laid for a defence relationship with Indonesia, involving joint training, technical assistance and a certain level of information exchange. Australia also maintained close security relations with Singapore and Malaysia under (from 1971) the Five Power Defence Arrangement, a legacy of the insurgency in the peninsula conducted by the Malayan Communist Party against the British colonial authorities (Millar 1991). 


\section{The Hawke-Keating governments}

Under the Hawke government (1983-91), the economic trends already discussed were enhanced by the movement towards the internationalization of the Australian economy. Not without political controversy and entailing significant dislocation to some industries, protection of domestic manufacturing was progressively abandoned. The Australian market was thereby opened to the rising industrial power of East Asia.

At this time Japan was already the world's second largest economy and, in part as a result of the export of Japanese capital, the Asian NIC economies were growing at an extremely rapid rate. Elsewhere in the Asia-Pacific region, some of the countries of Southeast Asia were experimenting with similar outward looking development models, and China's turn away from Maoist autarchy (from 1978) added enormous economic potential to an already large and increasingly integrated regional economy. The liberalization of the Australian economy drew in increasing imports from all of these economies while, simultaneously, Australia became a significant source for their exports of raw materials. By way of illustration, by 1990 a single company in Korea (POSCO) became the largest single importer of any Australian commodity (in this case, coal).

The Hawke government sought to manage these trends to maximize their advantage to Australia. In the late 1980 s a number of official and commissioned reports set out the government's regional agenda. Regarding population, in 1988 the Fitzgerald Report recommended that Northeast Asia in particular be seen as a potential source of skilled immigrants (Fitzgerald 1988). In 1989 Australia's Regional Security anticipated the emergence of new and cooperative security modalities embracing the entire region (DFAT 1989). The most important of these expressions of a distinctive approach to the Asia-Pacific region was the 'Garnaut Report', Australia and the Northeast Asian Ascendancy-authored by a team chaired by Australia's former ambassador to Beijing, which appeared in 1989.

Garnaut's argument was that for Australia to take best advantage of the rapid growth in the region, and especially in Northeast Asia, the domestic economy should be further liberalized (Gamaut 1989). Such liberalization should be accompanied by changes in training, travel, and education to make Australians more aware of the region and facilitate access to its cultures, cities and markets. Recognizing differences between Australia and its new partners in connection with political and social systems and values, Garnaut recommended taking a long term and pragmatic view. Rather than directly confronting illiberal practices regarding human rights policy, or lack of free expression, he argued that, as it was a general trend that the liberalization of social and political systems followed economic liberalization, therefore there would be a gradual convergence of these values. Meanwhile, Australia's most positive contribution in this area was to encourage a market orientation which, to an extent, required Australia to lead by example.

Though Garnaut's message received a good deal of bipartisan support, it was also subjected to a variety of critiques (Richardson 1991). Some commentators 
claimed that other lessons should be drawn from the success of the Asian economies, for example on the need for a targeted 'industry policy'; others suggested that the purported linkage between political and social liberalization did not always emerge in the unqualified way Garnaut suggested. But the breadth of support for many of his arguments indicated that Asia, and Northeast Asia in particular, were now major preoccupations for policy-makers.

As to the modalities best suited to entrench and institutionalize the growing complementarities between Australia and the Asian region, multilateral means were favoured by the Hawke and Keating governments. Here it should be recalled that the global context for these policies was the end of the Cold War and the deepening of economic and security cooperation across Europe evident in the functioning of such organizations as the CSCE/OSCE (Conference on Security and Cooperation in Europe) and the European Union. Accordingly, Australia was a founder member of APEC (in 1989) the conceptualization of which owed much to the Australian policy community. Similarly the (then) Foreign Minister, Gareth Evans, was one of the first advocates (in 1990) of a region-wide security architecture which was eventually realized in the ASEAN Regional Forum (1994) (Ball and Kerr 1996).

Nevertheless, other strands-old as well as new-could be detected in the fabric of foreign policy. The alliance with the United States remained fundamental in security calculations. In addition, Foreign Minister Gareth Evans became a prominent, if not always dexterous, practitioner of 'middle power activism' in connection with a wide range of issues, from global arms control-Australia making an especially significant contribution to the negotiation of the Chemical Weapons Convention (Findlay 1993)-tbrough the resolution of such perennial problems as the conflict in Cambodia to the building of international coalitions of agricultural producers to wrest fairer conditions of trade from the industrialized world (Cooper et al. 1993, 50-82). And Australia remained committed to the defence of Malaysia and Singapore under the 'Five Power' security agreement, an inheritance from the end of the British empire.

From time to time there were signs that all these many objectives and modalities produced incoherencies (Goldsworthy 2002). Strains emerged in the alliance with the US when the government sponsored an international inquiry - the Canberra Commission - that found the possession of nuclear weapons to have no moral basis, and correspondingly some of Australia's new security interlocutors remained sceptical of a country that espoused the notion of common security while relying upon links with a power perceived as a de facto regional hegemon. Neither were these policies without domestic controversy. Though there was much support in the wider political policy community and among elites for regional engagement, there was still some community scepticism and even unease that the 'Asianization of Australia' would follow (McAllister and Ravenhill 1998). Seen in the longer perspective, however, the considerable reorientation of Australia's external policy that occurred in these years was remarkably free of pain or controversy. 


\section{The transition to a Liberal-National Party coalition government}

Having run its course, the Labor administration was replaced by a Liberal-National coalition government led by John Howard in March 1996. At the outset, the new administration adopted quite a different tone in its approach to external issues. It described its philosophical position as 'realist' and defined its principal objective in this area as a pursuit of 'the national interest' defined in terms of the physical security of Australia and its citizens and their economic prosperity. In the words of the 1997 White Paper, In the National Interest,

\footnotetext{
Preparing for the future is not a matter of grand constructs. It is about the hard-headed pursuit of the interests which lie at the core of foreign and trade policy: the security of the nation and the jobs and standard of living of the Australian people. In all that it does in the field of foreign and trade policy, the Government will apply this basic test of national interest (DFAT 1997, iii).
}

Whereas in the Keating era republicanism was on the political agenda and aspects of the British inheritance and historical record were derided, Howard rejected such re-evaluations as the 'black arm band' school of history and, in a phrase that often occurred in public pronouncements declared: 'we do not have to chose between our history and our geography.' Accordingly, though the government did not reject the idea of 'engagement' with Asia, it was much more inclined to view this strategy as desirable only if it served 'the national interest' and if it did not require or encourage the abandonment of essential values and traditions-especially transparency and the rule of law. Nevertheless, Foreign Minister Alexander Downer (undoubtedly more internationalist in his outlook) tirelessly reiterated the message that 'engagement with Asia' was still the country's most important diplomatic task.

In other circumstances, the pursuit of foreign and defence policy under the Coalition government might in practice have resulted in little substantive variation from that of its predecessor. The Australian foreign policy debate, after all, had been characterized for many years by a considerable element of bipartisanship. The Howard government, however, soon had to grapple with developments in the region that overturned many of the established assumptions of the foreign policy community. The regional financial crisis that began in mid-1997 negated the widely shared expectation, as expressed in In the National Interest, that an increasingly prosperous Asia would inexorably bring Australia into its economic orbit while compelling a more judicious and nuanced approach by Canberra to more self-confident and perhaps even more assertive and capable neighbouring powers.

Within the space of a few months, the relatively benign and predictable regional environment became turbulent and uncertain. The political repercussions of the crisis, especially the attempted democratization of Indonesia, inevitably subjected past attempts to build bridges with regimes and leaderships in the region 
to new and critical scrutiny. But it was not just previous relations with individual regimes that came under question. The backlash of Asian governments against perceived western indifference to their financial plight, and the stimulus this gave to the creation of an East Asian identity, threatened to undermine Canberra's attempts at fostering regional organizations across the Pacific Rim.

The financial crisis highlighted the ambivalence in the Coalition's approach to the region. On the one hand, the government responded quickly and generously to the international relief programs for Thailand, Indonesia and then Korea. On the other, the crises provided an opportunity for the government to point to the distinctiveness of Australia's economic and even social systems as an explanation for why the nation was immune from the regional contagion (Wesley 2002). As the Foreign Minister remarked of Australia's record, 'what other country in the region has managed, in the face of the toughest economic conditions for fifty years, to maintain both strong economic growth and successfully renew democratic institutions through the holding of a free and fair general election?' (Downer 1999, 4). From being a pupil of the Asian dragons in the previous decade, Australia now volunteered itself as an instructor in the ways of reform. Australia's assumed role as tutor was not well received in many parts of the region. At the same time the government was successful in managing a significant reorientation in Australia's trade. In the first 12 months of the crisis, there was a 22 per cent increase of exports to the European Union and 40 per cent increase in exports to the United States.

ASEAN and APEC proved ineffectual in dealing with the crisis, and Canberra's somewhat sceptical approach to regionalism manifest after 1998 was in part a response to this poor performance. However, the Australian government still sought to use the latter as a basis for encouraging those reforms that would prevent a further recurrence of financial crisis, and attempted to pursue closer trade relations with the former through a proposed link between the ASEAN Free Trade Area and the Closer Economic Relationship agreement between Australia and New Zealand (a linkage eventually rejected by ASEAN).

The ineffectiveness of APEC, the organization that was the centrepiece of the previous government's strategy of economic engagement with Asia, generated two responses from the region to which the government was slow to respond. One was the formation of the ASEAN Plus Three grouping, which realized Malaysian Prime Minister Dr Mahathir's long-standing goal of creating a region-wide East Asian grouping specifically excluding Australia. The second development was a new interest, particularly on the part of Japan, Singapore, and Thailand, in the negotiation of bilateral discriminatory trade agreements. The government first rejected the relevance for Australia of the ASEAN Plus Three grouping and then lobbied to join it. And after decades in which Canberra had opposed bilateral trade agreements in support of its preferred alternatives of multilateralism and open regionalism, the Howard government belatedly adopted this strategy by seeking to negotiate free trade agreements with the United States, Singapore, and Thailand. 
To this extent, regional engagement was to be much more selective than in the past.

The Howard government's preference for closer cooperation with traditional allies and a more discriminating attitude towards regional and global institutions was challenged by developments not just in the region but throughout the world system. The growing interdependence of states-reflected in the emergence of global issues and opinions, and in the strengthening of global institutions and regimes-threatened more restrictive conceptions of the national interest with obsolescence. Global warming, the entrenchment of human rights standards, the proliferation of weapons of mass destruction, all demanded comprehensive solutions beyond the capacity even of groups of states. The financial crisis itself demonstrated the vuinerability of important economies to a world financial regime constructed on the foundation of new technologies in the $1990 \mathrm{~s}$.

Domestic political developments also challenged the Howard government's policies towards the region and on important global issues. Even in the less turbulent times of Prime Ministers Hawke and Keating, Australian elites were in some danger of outpacing popular opinion on many of the aspects of Asian engagement, from security to immigration (Cotton and Ravenhill 1997, 12-13). In a domestic development with significant and still continuing impact on Australia's external policies, the Howard government was forced to deal with a new political force seeking to mobilize voters in the name of what was alleged to be a growing gap between elite preferences and popular aspirations.

This force was manifest with the irruption of Pauline Hanson onto the political stage, first as an outspoken independent, then as the leader of a party that won some 23 per cent of the vote in the 1998 Queensland state elections, and (more significantly) 8.4 per cent of the vote in the federal election that returned the Coalition to office in that same year. Hanson was never clear on the policies to be used to achieve her goals, but she was outspoken on what she disliked. In her parliamentary maiden speech she complained of the actions of many malevolent agencies in Australia: 'financial markets, international organizations, world bankers, investment companies and big business people'. She also warned of the dangers of 'being swamped by Asians'. All of these phenomena could be traced to the impact of globalization on Australia, and to the government's partial dismantling of policies of social protection.

Although her party, 'Pauline Hanson's One Nation', disintegrated and she lost her federal parliamentary seat, the temporary revival of her movement at the end of 2000 and its undoubted influence on election results subsequently in state contests in Western Australia and Queensland illustrated that it might not be a transient phenomenon-and certainly that the fears that sustained such a populist movement were far from ephemeral. Moreover, it was a political force that posed the greatest threat to the Coalition, since those who voted for the party were largely individuals who had previously voted for the National or Liberal Parties (Jackman 1998). 
Hansonism presented the government with a powerful electoral motive to underscore its scepticism of regional engagement and its defence of a restricted conception of national interest. In what can be seen in retrospect as an extraordinarily active period in foreign policy making, the government's performance and utterances from 1997 especially regarding the Asia-Pacific region cannot be properly understood without a consideration of this domestic dimension. The most important policy innovation over these years was undoubtedly the decision to abandon support for Indonesian sovereignty in East Timor, a decision that led first to extensive and prominent support for the United Nations Mission in East Timor (UNAMET) ballot in the territory and then to the September 1999 military intervention.

\section{The implications of the East Timor intervention}

From a realist perspective, Indonesia is the key to Australia's defence. It commands the nation's northern approaches from which or through which any conventional military attack on Australia would be launched. A stable and friendly Indonesia is therefore crucial for Australia's security. From a common security perspective, there are added (or perhaps alternative) reasons for fostering good relations with Jakarta. Indonesia is the key to any wider multilateralist strategies for creating regional order. Indonesia is the dominant power in ASEAN, and this group is both the core of the ASEAN Regional Forum and the pioneer of the modalities for cooperation adopted by APEC. From this perspective, the negotiation of the 1995 'Agreement on Maintaining Security' with Indonesia was widely regarded as reconciling two potentially different conceptions of regional security and thus finally resolving the most important issue in Australia's strategic neighbourhood (Hartcher 1996).

If there is one policy that has had broad bipartisan support in the last 25 years it has been Indonesia's forcible annexation of East Timor (Cotton 1999). In acquiring the territory, Indonesia violated the international norm against aggressive and forcible action and also denied the right of the inhabitants to self-determination, these transgressions being reflected in the censure of Jakarta by the UN Security Council and the refusal of the UN to recognize the acquisition as legitimate. Nevertheless, Australia under a Coalition government extended de jure recognition to the annexation in February 1979, a position reaffirmed by the Hawke Labor government. The reasons for this policy were an uncertain and variable mix of the perceptions of Indonesia noted above. The decision by the Howard government to overturn this bipartisan legacy was the most significant development in policy towards the Asia-Pacific region since the Vietnam War.

Global changes constituted the background to (or preconditions for) this policy shift. These included the rise in the post Cold War era of the doctrine of intervention and also the fact that a democratizing Indonesia in economic crisis was more amenable than in past times to international pressure. But a novel understanding of Australia's regional role was undoubtedly a factor in the 
government's calculations. As the Prime Minister was reported to have said in a widely quoted magazine interview:

[The East Timor operation] has done a lot to cement Australia's place in the region. We have been seen by countries, not only in the region but around the world, as being able to do something that probably no other country could do; because of the special characteristics we have; because we occupy that special place - we are a European, Western civilization with strong links to North America, but here we are in Asia (Brenchley 1999, 24).

Australian leadership of the INTERFET (International Force East Timor) intervention in the territory in October 1999 was a watershed event. The impact of the East Timor commitment had nothing less than a profound effect on many aspects of Australia's regional security and defence posture. Australian-Indonesian relations were placed on a new footing, past and future regional engagement became the subject of vigorous debate, and defence priorities were re-ordered.

Relations with Indonesia took a wholly new course with the intervention. Prior to 1999 , there were expectations that the emergence of democracy in Indonesia, especially in the context of Australia's US $\$ 1$ billion contribution to the International Monetary Fund relief package provided as a response to the regional financial crisis, would put relations with Jakarta on an entirely new basis. Australian support for the infrastructure necessary to stage the 1999 parliamentary elections was indicative of the awareness that the progress of democratic consolidation was vital for Australia's national interests. But this support counted for very little in the balance as against what was widely represented in the Indonesian media as Australia's 'arrogance' and 'betrayal' over East Timor. This perceived hostility stirred passions. A vehicle carrying the Australian Ambassador was shot at in Dili. After the Defence Minister stated that all bilateral defence contacts with Indonesia were suspended, Indonesia announced on 16 September that the 1995 bilateral Agreement on Maintaining Security would be abrogated. The agreement was then dismissed by the government as of little consequence, but its demise marked the end of a defence relationship painstakingly constructed from the 1960s. As the INTERFET operation began, demonstrators gathered outside the Australian embassy and there were violent incidents. And President Wahid himself described Australian policy as 'infantile' (Antara, 30 September 1999; Hill and Manning 1999; Bhakti 1999).

Despite strenuous diplomatic efforts, including a visit to Jakarta by Foreign Minister Downer in February 2000, relations with Indonesia remained in an awkward phase. Ironically President Abdurrahman Wahid was personally very familiar with Australia and was also extremely fond of overseas travel, yet he could only be tempted to visit the country in the twilight of his presidency. It was therefore something of a surprise that Prime Minister Howard was invited to meet his successor, Megawati Sukarnoputri, immediately upon her taking office. The two leaders met again in 2002 when they agreed to measures of bilateral 
cooperation in the international campaign against terrorism. In an area of great concern to Australia, the transit through Indonesia of people smuggling networks, much work however remained to be done.

Finally, Australian intervention in East Timor was seen as a possible harbinger of future interference in Indonesia's internal affairs, especially in connection with West Papua. Despite strenuous denials from the Australian government, this suspicion was encouraged by statements from Colin Powell, shortly after being nominated by President-elect Bush as the new US Secretary of State. In remarks he made during confirmation hearings, he signalled a new scepticism of humanitarian interventions, and indicated that more reliance would be placed on allies, specifically referring to Australia's decision to 'take the lead' regarding Indonesia (Sydney Morning Herald, 19 January 2001). These remarks found an attentive audience in Jakarta.

If there was uncertainty in Indonesia regarding Australia's intentions in the region, this was a consequence not only of the nation's role in UNAMET and INTERFET, but also a reaction to the very public debate that the latter engendered. While Australian forces were committed to Timor with the undoubted expectation that there would be loss of life, the success of the operation led to statements from political and military figures that seemed to imply a larger if indeterminate commitment to similar undertakings in the future. For a short period the 'Howard doctrine', by which this position came to be known, depicted Australia as playing a role as a 'deputy' to the US in keeping the regional peace (Lyons 1999).

According to the government's account, the objectives of the East Timor intervention were threefold. First a perennial problem in Australia-Indonesia bilateral relations was being addressed. It was incontrovertible that the perception of Indonesia's human rights record in East Timor had been an obstacle to a more favourable public assessment of that country for a generation. Second, and in light of the fact that the UN still held Indonesian occupation to be illegitimate, a new status for East Timor would remove perhaps the major obstacle to Indonesia playing a positive role in the world, commensurate with its size and potential. Third, the intervention was a response to the very strong reaction in the Australian public that was prompted by the violence and suffering experienced by the East Timorese in the aftermath of the ballot.

It was the fate of the Timor issue, despite the very particular circumstances that led both to the Australian policy change and also to the NTERFET intervention, to tend to be generalized into a novel and path-breaking national approach to the region. In the parliamentary debate of 21 September 1999 on the issue, the Prime Minister used the opportunity to outline some 'home truths' regarding Australia's position in the region. Though not as outspoken as the putative 'Howard doctrine', this statement represented the most distinctive and considered contribution by the Prime Minister to foreign policy discourse since he assumed office in 1996. The first of these truths was that foreign policy must be based on a clearer sense of 'national interest' and 'values'. The national interest requires Australia to pursue 
relationships on the basis of mutual interest and to recognize 'where they exist, differences in values and political systems.' Secondly, Australia occupies 'a unique intersection-a western nation next to Asia with strong links to the United States and Europe' and therefore commands 'unique assets.'

We have stopped worrying about whether we are Asian, in Asia, enmeshed in Asia or part of a mythical East-Asian hemisphere. We have got on with the job of being ourseives in the region. In turn, the region has recognized that we are an asset and have a constructive role to play in it (Commonwealth Parliamentary Debates 21 September 1999, 10029).

The assets listed include the ANZUS and Five Power security alliances, and also bilateral defence cooperation programs. However, the alliance with the US was then identified as a separate (third) truth, and was described as functioning 'very effectively', having helped deliver a significant US contribution in this instance. Adequate defence resources were the fourth truth, and as the prevailing security climate was 'uncertain', these resources were apparently insufficient, and additional expenditure was thus foreshadowed. The fifth and final truth was the need to take account of 'the values of the Australian community', and the inference to be drawn from this was that Australia should not seek 'a good relationship with Indonesia at all costs or at the expense of doing the right thing according to our own values.' In each one of these 'truths' may be detected a statement of the distinctiveness, by comparison with the region, of Australia's identity and interests.

Returning to the issue of Australia's regional assets, John Howard contrasted his approach with that of some commentators who maintained that under his tenure Australia would be excluded from regional frameworks and thus would never be accepted in Asia. This underestimated Australia's capacities and institutions, especially as demonstrated by the nation's positive performance during the Asian economic crisis:

...our economic, military and other credentials are respected and give us a capacity to help and constructively participate in the region. Just as we were in a position to assist our neighbours during the Asian economic crisis, so also on East Timor we have shown that we have the capacity under the United Nations to work with our regional partners in putting together a multinational peacekeeping force. It is an example of both our commitment to the region and our capacity to make a constructive and practical contribution to its affairs (Commonwealth Parliamentary Debates 21 September 1999, 10031),

On this understanding of Australian foreign policy, the Timor commitment was consistent with the national interest in two respects. Australian forces were being used in the service of international institutions and with Indonesian consent to assist the East Timorese to realize the choice they had made in an internationally supervised ballot. And these forces, by suppressing violence, would restore regional order and end uncertainty. But the issue of whether Australia's putative 
'assets' were entirely welcome in the region was not considered. Moreover, the enhanced military preparedness that would allow Australia to embark on a similar intervention in the future might conceivably be seen as a threat rather than a positive contribution to regional order, and was certainly represented as such by Australia's critics. Indeed, Malaysia's Prime Minister Dr Mahathir was forthright in his criticism of Australia's regional designs, though other criticism expressed in Southeast Asia was more muted (South China Morning Post, 27 September 1999). However these developments are to be interpreted, Australia's willingness to employ military force marked virtually the end of the policy of 'regional engagement' principally by way of participation in multilateral institutions and the practice of consensus diplomacy.

Finally, the East Timor experience had a powerful impact on security perceptions. Australian forces performed well during the crisis of 1999 , especially given the immensely difficult logistics involved in inserting and supporting in a potential hostile theatre a multinational force the components of which had no prior experience of working together. Yet the commitment revealed potential lack of capacity, and as a result the 2000 Defence White Paper stated a commitment to significant increases in expenditure, albeit over a ten year period (Department of Defence 2000). Such expenditure increases were already expected, given the problem of block obsolescence in much defence equipment. What was unprecedented in the White Paper was the clear statement that after the defence of continental Australia, 'lower level operations' including peacekeeping are the next most important priority for the ADF (Australian Defence Force), and that other features of the East Timor experience may recur:

This might require the ADF to contribute to regional peacekeeping and humanitarian relief operations and help evacuate Australians and others from regional troublespots. We should be prepared to be the largest force contributor to such operations. Our planning needs to acknowledge that we could be called upon to undertake several operations simultaneously, as we are at present in East Timor, Bougainville and the Solomon Islands (Department of Defence 2000,39).

What scenarios are anticipated here? The White Paper underlines the strategic primacy of Indonesia, and states that Australia's security would be threatened by 'adverse developments' inside Indonesia, whether internally or externally generated (Department of Defence 2000, 22).

On East Timor, the White Paper signals nothing less than a continuing security commitment:

Within a short time East Timor will pass from UN authority to full independence. Australia will seek to develop an effective defence relationship with East Timor...East Timor faces formidable security challenges. Our aim will be to provide, with others, an appropriate level of help and support for East Timor as it builds the capabilities and national 
institutions that it will need to ensure its security and thereby contribute to the security of its neighbourhood (Department of Defence 2000,37).

A week before the document was released to the public, the Defence Minister announced a \$A26 million aid program to help train and equip a defence force, the core of which was being drawn from FALINTIL, the guerrilla resistance army that was for a generation the Indonesian military's most dogged opponents (The Australian, 24 November 2000). Nor will relations with independent East Timor necessarily be harmonious on this account or even in light of the A $\$ 150$ million of aid promised by the government in 2000 for a four-year period. (Australian Agency for International Development 2001) In short, Australia is now committed to the protection and development of a country the birth of which constitutes Indonesia's greatest policy reversal in all of its history as a nation. In this context it should be acknowledged that the message of the intervention for the region was decidedly mixed. Some ASEAN states participated in the INTERFET operation, but there were also some expressions of dismay and distrust at what was presented as the humiliation of Indonesia and its armed forces by an external power.

In retrospect, this shift in policy is in part testimony to the weaknesses and limitations of those multilateral institutions that had been the preferred mechanisms for regional engagement prior to the 1997 regional crisis. Since 1967 ASEAN has been committed to principles of non-interference in the affairs of other states, the pacific resolution of disputes, and an avoidance of external power entanglements. Indonesia's invasion of East Timor violated all of these principles not least because the Indonesian military became dependent thereafter on US military matériel and assistance. Yet East Timor was never a matter raised within ASEAN; indeed, the ASEAN countries maintained a united international front on the issue (Inbaraj 1995). The reasons for this solidarity are not far to seek, but this episode may be taken to illustrate that such principles are only as determining of state conduct as power relations permit. Even in September 1999, when faced with the most significant regional security crisis since Vietnam's invasion of Cambodia, the ASEAN role was marginal, the group's foreign ministers initially even resisting discussing East Timor at the APEC summit in Auckland. If this was a non-subject for ASEAN, then it was never likely to appear on the agenda of the ASEAN Regional Forum. Without pursuing this issue too far, it may even be argued that these institutions were part of the problem, since they legitimized the Indonesian regime as a credible actor and made its cooperation vital to regional order. The inability of the ASEAN Regional Forum even to discuss the Taiwan issue, despite the fact that (in some scenarios) it may lead to a major East Asian war, is a further illustration of the limitations of such diplomatic mechanisms (Lim 1998). Now these arguments are not the kind that any government spokesperson is likely to articulate publicly, but their logic supports the realist turn that became evident in foreign policy pronouncements from 1996. 


\section{The regional burdens of alliance}

The East Timor commitment constituted a significant test of the alliance with the United States, while also appearing to underline the necessity for realist calculations in an environment where multilateral mechanisms are ineffective. Despite some anxious moments in Canberra, the United States agreed to join the NNTERFET coalition and in announcing this policy President Clinton specifically cited the alliance with Australia as a major consideration in his decision (Cotton 2001). It should be recalled that US arms supplies were indispensable in facilitating the pursuit by the Indonesian military of the East Timorese resistance army, and the US was associated from the very beginning with the annexation by virtue of (then) Secretary of State Henry Kissinger's encouragement of the policy (National Security Archive 2002). And despite the relatively small number of US personnel involved, Washington's role in 1999 was crucial. US diplomatic leverage (not least within the Bretton Woods institutions) impelled the Indonesian government to sanction the INTERFET operation. In the uncertain and potentially hostile environment of East Timor, US intelligence assets and heavy lift capability were vital (Schwartz 2001).

Indeed, in 2000 and into the Bush administration, US spokespersons were willing to cite the Australian role in East Timor as an example of the more selfreliant alliance model they wished to see world-wide, with the local partner in the alliance relationship taking the initiative and providing many of the forces (and footing much of the bill) while Washington provided diplomatic, intelligence and logistics support. Comprehensive cooperation with Washington however requires 'interoperability' of platforms and systems, and in anticipation of further regional crises Australia now faces some difficult choices if it is to remain a full member of the alliance.

The Revolution in Military Affairs (RMA) promises to transform conflict into a contest in which superior technologies deliver mastery (Cohen 1996). Australia had traditionally relied upon the possession of advanced armaments and information technologies to offset the disadvantages of its small population and immense territory. As part of the UKUSA network Australia has engaged in intelligence sharing with the United States since the early years of the Cold War (Richelson and Ball 1985). To participate in the RMA, according to some specialists, not only must Australia source its most advanced systems exclusively from the United States but it must also be unambiguously part of a global partnership centred upon the United States, the framework of which derives from the bilateral alliances forged during the Cold War. If realist calculations are presently influential in Canberra, then this outcome may have its attractions. However, realism also may prescribe the maintenance of the current regional strategic balance which might, in some interpretations, be prejudiced by the development of such new systems as National Missile Defence. In addition, Australia's policy-makers may be convinced that bans on devices such as chemical weapons, biological weapons, or landmines may enhance global security, but may 
come under pressure to abandon their criticisms of them in the interests of alliance solidarity. These and other concerns were the context for the 2001 AustralianUnited States Ministerial talks, conducted in Canberra in late July 2001 (Pearson 2001).

Setting aside questions involving specific security decisions made by the United States, there is some room for the argument that close security cooperation with other US strategic partners in the Asia-Pacific region is not necessarily in the national interest. Both Japan and the Republic of Korea are important economic partners of long-standing, and (at least on paper) Australia is still a guarantor of Korean security by virtue of its participation in the Korean War. Greater cooperation with these partners would be consistent with many national objectives. But if the United States is to revive its security relationship with the Philippines, then, as part of a regional network of states, Australia may find itself embroiled as part of a coalition in a conflict over territorial claims in the South China Sea. Similarly, the informal alliance that binds the United States to Taiwan may draw Australia into a dispute between the major regional powers. Again, Taiwan is an important trading partner and is now a prominent example of a regional democracy, but direct conflict with China cannot enhance Australia's national security (Blackwill and Dibb 2000; McDonald 2001). Commentators in China were not slow to point this out, in response to the outcome of the July AusMin proceedings (Dwyer 2001). Australia's role in the post-September 11 'war against terrorism', though undertaken to serve security objectives, has increased further the potential risks associated with the prevailing alliance strategy.

\section{Conclusions}

Through the 1980s to the regional financial crisis of 1997 , the idea that there was a natural complementarity between Asia and Australia-firstly understood in economic terms, but then with respect to immigration, security, and even diplomacy - became increasingly influential. Now this idea was never universally accepted, but it was often encountered and became something like the established view. This idea no longer represents majority opinion. In all of these areas there are far more uncertainties than was acknowledged at that time. As this chapter has argued, the reasons for this shift are many, but include the failure of regional institutions to make a real impact on economic and security problems, the election of a government somewhat sceptical of the multilateralist predilections of its predecessors, and domestic political dynamics.

In assessing these changes some critical comments are in order. It may be that this change of emphasis reflects the demise of those conditions from the 1980 s that provided the foundations for regionalism. In short, regionalism may be a moment whose time has passed. Globalization-of finances, of information flows, of tastes and trends, of security -may have undermined the capacity of such organizations as ASEAN to have a real impact in the long run. Distance has always been Australia's biggest obstacle to progress. Australia, more than any other place, 
needs to globalize. A specific regional attachment may no longer be appropriate or efficacious.

But the point remains that the regional financial crisis as much as the Hanson movement was a manifestation of globalization. In a genuinely global era, the relevance of a narrow conception of national interest may no longer be applicable. However much a triumph of Australian arms or values, the East Timor intervention would never have been possible without the attention of transnational interest groups, the weakening of the Indonesian government as the result of the activities of the global financial system, and the continued concern about the issue maintained by the United Nations. In pursuit of a hard-headed national interest, Australian policy has inevitably been conditioned and constrained as well as facilitated by the growing interdependence of nations. Therefore, a lack of attention to building institutions to deal with issues which, while they have a regional dimension are nevertheless truly global, including the environmental crisis, refugee flows and human rights abuses, may no longer accord with national interest, however this term is understood.

\section{References}

Antara (Jakarta)

Australian Agency for International Development (AUSAID). 2001. East Timor Update, 17 January. Canberra: AUSAID.

The Australian (Sydney)

Ball, Des, and Pauline Kerr. 1996. Presumptive Engagement: Australia's Asia-Pacific Security Policy in the 1990s. North Sydney: Allen and Unwin.

Bhakti, Ikrar Nusa, 1999. 'Howard Sets Back RI-Indonesia Ties', Jakarta Post, 12 September, p.4.

Blackwill, Robert D., and Paul Dibb (eds). 2000. America's Asian Alliances. Cambridge: Massachusetts Institute of Technology Press.

Brenchley, Fred. 1999. 'The Howard Defence Doctrine'. The Bulletin, 28 September.

Casey, R.G. 1955. Friends and Neighbors. Australia, the US and the World. East Lansing: Michigan State College Press.

Cohen, Eliot A. 1996. 'A Revolution in Warfare', Foreign Affairs. 75:2, pp.37-54.

Commonwealth Parliamentary Debates (Canberra).

Cooper, Andrew F., R.A. Higgott and K.R. Nossal. 1993. Relocating Middle Powers. Australia and Canada in a Changing World Order. Melbourne: Melbourne University Press.

Cotton, James. 1999. 'East Timor and Australia-Twenty-five Years of the Policy Debate'. In James Cotton (ed.), East Timor and Australia. Canberra: ADSC/AllA.

Cotton, James. 2001. 'Against the Grain: The East Timor Intervention', Survival. 43:1, pp. $127-42$.

Cotton, James, and John Ravenhill. 1997. "Australia's "Engagement with Asia"'. In James Cotton and John Ravenhill (eds), Seeking Asian Engagement: Australia in World Affairs 1991-95. Melbourne: Oxford University Press, pp.1-16. 
Department of Defence. 2000. Defence 2000: Our Future Defence Force, Canberra: Department of Defence.

DFAT (Department of Foreign Affairs and Trade). 1989. Australia's Regional Security: Ministerial Statement. Canberra: DFAT.

DFAT (Department of Foreign Affairs and Trade), 1997. In the National Interest: Australia's Foreign and Trade Policy. Canberra: DFAT.

Downer, Alexander. 1999. 'Australia and Asia-A New Paradigm for the Relationship', Speech to the Foreign Correspondents' Association (Sydney: 16 April 1999): <www.dfat.gov.au/media/speeches/foreign/1999/990416_aust_asia.html>

Dwyer, Michael. 2001. 'China Attacks "another NATO", Australian Financial Review, 2 August, p.10.

Edwards, Peter, with Greg Pemberton. 1992. Crises and Commitments: The Politics and Diplomacy of Australia's Involvement in Southeast Asian Conflicts 1948-1965. North Sydney: Allen and Unwin.

Findlay, Trevor. 1993. Peace Through Chemistry: The New Chemical Weapons Convention. Canberra: Australian National University, Peace Research Centre Monograph 14.

Fitzgerald, Stephen. 1988. Immigration: A Commitment to Australia. Canberra: AGPS.

Garnaut, Ross. 1989. Australia and the Northeast Asian Ascendancy. Canberra: AGPS.

Goldsworthy, David. 2002. 'An Overview'. In J. Cotton and J. Ravenhill (eds), The National Interest in a Global Era: Australia in World Affairs 1996-2000. Melbourne: Oxford University Press.

Grey, Jeffrey. 1999. A Military History of Australia. Cambridge: Cambridge University Press.

Hartcher, Peter. 1996. 'How the Enemy Became an Ally', Australian Financial Review, 4-5 July, pp. 1, 18-19, 26-7.

Hill, Hal, and Chris Manning. 1999. 'Indonesia-Australia Ties-What Went Wrong', The Jakarta Post (Jakarta), 30 November, p.4.

Inbaraj, Sonny. 1995. East Timor: Blood and Tears in ASEAN. Chiangmai: Silkworm Books.

Jackman, Simon. 1998. 'Pauline Hanson, the Mainstream, and Political Elites: The Place of Race in Australian Political Ideology', Australian Journal of Political Science. 33:2, pp. $167-84$.

Keating, Paul. 2000. Engagement: Australia Faces the Asia-Pacific. Sydney: Pan Macmillan.

Lim, Robyn. 1998. 'The ASEAN Regional Forum: Building on Sand', Contemporary Southeast Asia. 20:2, pp.115-36.

Lyons, John. 1999. 'The Howard Doctrine', The Bulletin, 28 September, pp. 22-4.

McAllister, Ian, and John Ravenhill. 1998. 'Australian Attitudes towards Closer Engagement with Asia', The Pacific Review. 11:1, pp. 119-41.

McDonald, Hamish. 2001. 'Don't Mention the Sleeping Giant', Sydney Morning Herald, 31 July.

Mackie, Jamie. 1997. 'The Politics of Asian Immigration'. In James E. Coughlan and Deborah J. McNamara (eds), Asians in Australia: Patterns of Migration and Settlement. South Melbourne: Macmillan, pp. 10-48.

Meredith, David, and Barrie Dyster. 1999. Australia in the Global Economy. Cambridge: Cambridge University Press. 
Millar, T.B. 1991. Australia in Peace and War: External Relations since 1788. Canberra: Australian National University Press.

National Security Archive. 2002. 'East Timor Revisited': $<$ www.gwu.edu/ nsarchiv/NSAEBB/NSAEBB62/>

Pearson, Brendan. 2001. 'Powell Floats Idea of Asia-Pacific Security Bloc', Australian Financial Review, 31 July, p.1.

Pemberton, Greg. 1987. All the Way: Australia's Road to Vietnam. North Sydney: Allen and Unwin.

Richardson, James L. (ed.). 1991. Northeast Asian Challenge: Debating the Garnaut Report. Canberra Studies in World Affairs no 27. Canberra: Department of International Relations, Australian National University.

Richelson, Jeffrey T., and Desmond Ball. 1985. The Ties that Bind: Intelligence Cooperation Between the UKUSA Countries. Boston: Allen and Unwin.

Schwartz, Eric. 2001. 'A Reminder That Friends in Deed are Friends Indeed', Sydney Morning Herald, 24 July, p. 12.

Spender, Percy. 1969. Exercises in Diplomacy. Sydney: Sydney University Press.

South China Morning Post (Hong Kong)

Sydney Morning Herald (Sydney)

Tweedie, Sandra. 1994. Trading Partners: Australia and Asia 1790-1993. Sydney: University of NSW Press.

Wesley, Michael. 2002. 'Australia and the Asian Financial Crisis'. In J. Cotton and J. Ravenhill (eds), The National Interest in a Global Era: Australia in World Affairs 1996-2000. Melbourne: Oxford University Press.

Whitlam, E.G. 1981. A Pacific Community. Cambridge: Harvard University Press. 